\title{
Topics in Contemporary Legal Argumentation: Some Remarks on the Topical Nature of Legal Argumentation in the Continental Law Tradition
}

\author{
GUENTHER KREUZBAUER
}

\author{
University of Salzburg \\ Department of Social Sciences and Economics \\ Churfuerststr. 1, 5020 Salzburg \\ guenther.kreuzbauer@sbg.ac.at
}

\begin{abstract}
The article discusses topics in the context of contemporary legal argumentation. It starts with a sketch of the development of topics from ancient times until the present day. Here the author focuses on the theory of the German legal philosopher Theodor Viehweg, which was most influential to legal argumentation in the 20th century. Then a modern concept of topics is introduced and finally the author discusses the role of topics in contemporary legal argumentation. In this part the distinction between topoi in the weak sense (practically all argumentation schemes) and in the strong sense (specific legal topoi as listed by Gerhard Struck in 1971 is introduced. The author argues that Viehweg's claim that topics plays an important role in legal argumentation is problematic, because topoi in the weak sense are certainly of high importance, but this is almost trivial. Topoi in the strong sense on the other hand are only of minor importance for legal practice. What characterises legal discourse much more is a set specific pragmatic discourse rules, discussed at the end of the paper.
\end{abstract}

Résumé: Cet article discute des topiques dans le contexte contemporain d'argumentation légale. Il commence avec une ébauche du développement des topiques de l'antiquité jusqu'à nos jours. L'auteur concentre son attention sur la théorie du philosophe du droit allemand de Theodor Viehweb, qui fut le plus influent sur l'argumentation du droit au $20^{\mathrm{e}}$ siècle. L'auteur introduit ensuite un concept moderne des topiques, et discute du rôle des topiques dans l'argumentation légale contemporaine, et de la distinction entre topoi au sens faible (qui inclut presque tous les schèmes argumentatifs) et au sens fort (selon spécifiquement le topoi légal avancé par Gehard Struck en 1971). L'auteur soutient que l'affirmation de Viehweg que les topiques jouent un rôle important dans l'argumentation légale est problématique, car bien que les topoi au sens faible aient une grande importance, ceci est quasiment insignifiant. D'autre part, les topoi au sens fort ont seulement une importance secondaire dans la pratique judiciaire. $\mathrm{Ce}$ qui caractérise le discours légal est plutôt un ensemble de règles discursives pragmatiques et spécifiques.

Keywords: argumentation schemes, Aristotle, discourse rules, legal argumentation, legal discourse, more geometric, pragmatics, rationality, Theodor Viehweg, topics 


\section{Introduction}

In 1953 the German legal philosopher Theodor Viehweg (1907-1988) published his well-known book Topik und Jurisprudenz: Ein Beitrag zur rechtswissenschaftlichen Grundlagenforschung (Viehweg 1974 [1953] ${ }^{1}$ ) (English: Topics and Law: A Contribution to Basic Research in Law [Viehweg 1993]). Therein Viehweg claimed that legal argumentation is essentially topical, that it is important to take account of this topical quality in order to understand the very nature of law, and finally that topics would provide an appropriate legal methodology. ${ }^{1}$ With these claims Viehweg started the modern debate (see Horn 1967, 13-14) about topics in argumentation. On this basis, this paper aims to discuss exactly what constitutes the topical approach to legal argumentation. After defining some of the necessary concepts, we shall provide a brief overview of the topical approach to argumentation and finally discuss the relevance of topics for modern legal argumentation.

The first core concept we have to define is "argumentation". A commonly accepted definition is provided by Frans van Eemeren and Rob Grootendorst (2004, 1): "Argumentation is a verbal, social, and rational activity aimed at convincing a reasonable critic of the acceptability of a standpoint by putting forward a constellation of propositions justifying or refuting the proposition expressed in the standpoint." We can interpret this definition as signifying that argumentation is a cognitive activity (arg.: "verbal [...] and rational activity") and also a discursive activity (arg.: "aimed at convincing a reasonable critic"). By the latter we mean a communicative activity producing text in interaction among agents. The cognitive part of argumentation can be separated from the discursive, because if we argue silently with ourselves in an inner dialogue, there is no discursive dimension at all. This non-discursive part of argumentation is a kind of thinking, i.e., "the systematic transformation of mental representations of knowledge to characterize actual or possible states of the world, often in service of goals" (Holyoak \& Morrison 2005, 2).

However, what distinguishes argumentation form other types of thinking (such as mental calculation, creative thinking, etc.) is the trivial fact that it is based on arguments: argumentation means the construction, assembling and managing of arguments. For the concept of argument we use the definition offered by Irving M. Copi and Carl Cohen in their classic textbook on logic (Copi \& Cohen 2002, 6): “An argument is any group of propositions of which one is claimed to follow from the others, which are regarded as providing support or grounds for the truth of that one." Arguments, then, consist of premises and conclusions, bound together by inferential structures. The premises stand at the start of the inference process, the conclusions at its end. Thus premises are the input

\footnotetext{
${ }^{1}$ Viehweg does not formulate these claims explicitly; nevertheless they can be derived from Viehweg 1974, 95-110.
} 
and conclusions are the output of the argumentative inference processes. The most basic form of any argument reads: " $\mathrm{A}[=$ set of premises $]$ therefore B [= conclusion]" (see Kopperschmidt 2000, 55). The nondiscursive part of argumentation is equivalent to reasoning, because-if we follow Keith J. Holyoak's and Robert G. Morrison's Cambridge Handbook of Reasoning and Thinking - reasoning is the type of thinking that relies on the "process of drawing inferences (conclusions) from some initial information (premises)" (Holyoak \& Morrison 2005, 2). Thus reciting a poem or recalling sports statistics, for instance, needs a lot of thinking but usually no reasoning, whereas playing chess does.

Finally, when we speak about "legal argumentation" and "legal reasoning" we shall understand this very broadly as argumentation and reasoning with any connection to the realm of law.

\section{Historical development of topical reasoning}

It is widely accepted that although some pre-Aristotelian concepts of topics do exist (see for instance Sprute 2000) the first important step in

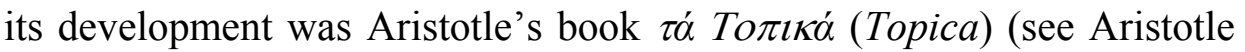
1963). This relates to the Greek word ' $\tau$ ' $\pi$ os' ('topos'), which-like the Latin word 'locus' means 'place' or 'location'. Henceforth we shall use

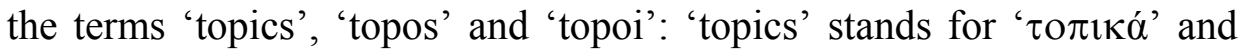
shall be understood as a set of topoi. Argumentation and reasoning with topoi shall be called 'topical argumentation' and 'topical reasoning'.

Aristotle writes about his Topica: "Our treatise proposes to find a line of inquiry whereby we shall be able to reason from opinions that are generally accepted about every problem propounded to us, and also shall ourselves, when standing up to an argument, avoid saying anything that shall obstruct us." (Aristotle 1963, 100a). But despite its provenance, "topics" does not count amongst the most popular concepts of philosophy-some philosophical encyclopaedias contain no corresponding entry-but are much more important in rhetoric and argumentation theory.

Topics is undeniably a mainly pre-modern systematisation of reasoning (and argumentation), one which many of its later proponents, especially Giambattista Vico (1668-1744) and Theodor Viehweg (19071988) saw in opposition to Cartesian rationalist reasoning-mostly associated with the French philosopher René Descartes (1596-1650) (Vico 1963, 27-37; Viehweg 1974, 15-18; see Goldmann 1998, 1282). Vico called the Cartesian rationalist style of thinking "critica" (Vico 1963, 20; Viehweg 1974, 17). He characterized it as a kind of reasoning that begins with a "primum verum" (by which he meant premises that are

${ }^{2}$ Original with italics. 
taken "to be resistant against refutation by doubt"3 [Viehweg 1974, 17]) and which proceeds further in a geometrical style (i.e., reasoning adhering to the ideals of Euclidian geometry by chains of syllogisms [Viehweg 1974, 17]). This type of reasoning is sometimes called reasoning "more geometrico" (cf. Wolters 1984) and implies reasoning using the technique of axiomatic systems ${ }^{4}$. It is almost a truism that it was rather this kind of rationalism and not topical reasoning that made modern mathematics and thus natural sciences possible.

There have been many attempts to categorise topoi (see Conley 2000, 579-583): Aristotle, for instance, used his four predicables (property, definition, genus and accident [Aristotle 1963, 101b]), for this purpose. Alexy $(1991,39-43)$ differentiates between three meanings of the concept "topics" (as a technique of finding premises, a theory about the nature of premises and a theory about the appropriate use of these premises in legal argumentation). In one of the most recent contributions available, Kalivoda distinguishes between seven types of topoi (mnemotechnical, argumentative-dialectical, material, figurative, categorising, classifying, collecting [Kalivoda 2007, 131]) and Primavesi, in his article on topics in the Historisches Wörterbuch der Philosophie of 1998 - probably the best short introduction to the history of topicsdistinguishes between three main categories: (1) topoi in the constructive sense, (2) topoi in the mnemonic sense and (3) topoi in the material sense (Primavesi 1998, 1263-1264). We follow this categorisation:

Ad 1: Topoi in the constructive sense: According to Primavesi, it was Aristotle who first used the term 'topos' in this sense, because he proposed to employ topoi as heuristic tools for the methodical construction of arguments (Aristotle 1963, 100a-100b; see Primavesi $1998,1263)$. But this holds only for dialectical discourse, which is only one out of Aristotle's three types of discourse, which are (1) apodeictic [demonstration], (2) dialectical and (3) eristic [contentious] discourse (Aristotle 1963, 100a-100b). This is so, because for him the task of topical reasoning is to find premises that are collectively accepted (see Aristotle 1963, 100a). Since premises of apodeictic discourse are more than this, because they are "true and primary" (Aristotle 1963, 100a) and premises of eristic discourse are less, because not even accepted, there is no room for topical reasoning therein.

Ad 2: Topoi in the mnemonic sense: According to Rapp (2002, 10; see also Primavesi 1998, 1263) the word topica in the context of rhetoric and argumentation was most probably first used as a general term for the places of a virtual image applied for a method of memorising

\footnotetext{
${ }^{3}$ Translation by the author.

${ }^{4}$ Axiomatic systems are usually used to model reality. They contain a finite-usually small - set of explicitly stated first sentences, the axioms. All other sentences of the system, the theorems, can be logically derived from the axioms. Thus if axiomatic systems are used for modelling, this provides a picture of reality with a perfect inherent systematic order.
} 
items. If a student of argumentation theory, for instance, has to memorize the classical fallacies, she could apply the technique of anthropomorphism and imagine them as persons living in tidy little houses on a virtual street in the virtual suburbs. So, for recalling the fallacies she imagines herself walking along this fictional street and naming all the residents.

Ad 3: Topoi in the material sense: Here the word designates some standardized conceptual and/or propositional items (Primavesi 1998, 1263). Cicero, the second most important ancient source of topics, used the concept in this sense. He dealt with topics especially in his Topica (Cicero 1993). As for Aristotle, for Cicero topoi are not arguments themselves (Primavesi 1998, 1268) and referring to pre-Aristotelian ideas, Cicero developed his concept of the "locus communis" ("commonplace") (Gethmann 1996, 320; Schirren 2000, XIV). Fuhrmann (2000, 51-52) emphasises that Cicero's Topica does not stand in the rhetorical but in the legal tradition. This is early evidence for a link between topics and legal argumentation.

The most important scholar of topics after Cicero was most probably the Neapolitan philosopher, historian and legal scholar Giambattista Vico (1668-1744), mentioned above, to whom Theodor Viehweg refers extensively. Vico saw topical reasoning as being in opposition to Cartesian rationalist reasoning and argued in favour of a higher reputation for topical reasoning. One of his arguments was that even if we reason the Cartesian rationalist way, running through a catalogue of topoi is required before we can be sure about a certain state of affairs (Goldmann 1998, 1282). So, for him the use of topoi was only a first step in what he called synthetic geometry, which he considered to be an alternative to Cartesian analytic geometry (Goldmann 1998, 1282). After Vico, topics was mostly forgotten by philosophy. So in our brief account we shall skip the developments until the rediscovery of topics by Theodor Viehweg in the 20th century.

The most important proponent of topics within the theory of legal argumentation and reasoning is Theodor Viehweg, whose abovementioned book Topik und Jurisprudenz: Ein Beitrag zur rechtswissenschaftlichen Grundlagenforschung (Viehweg 1974) contains an extensive discussion of the positions of Aristotle and Cicero, upon which he built his own theory. Viehweg remarks that although Euclidian geometry - the source of Cartesian rationalist reasoning — already existed in the age of Roman law (and was familiar to the educated élite), almost all Roman lawyers applied a non-systematic style of reasoning (Viehweg 1974, 50). They followed an informal, casuistic approach, which Viehweg saw as being based on problem-oriented thinking (Viehweg 1974, 49). This constitutes the first category of his dichotomy between problem-oriented and systematic thinking (by which he means Cartesian rationalist reasoning). Viehweg states that the starting point of each science is a problem that has to be solved. There are disciplines that may find some fruitful first (or basic) sentences, others do not. If fruitful first 
sentences exist, a field can be systematised; otherwise not. In the latter case the only possibility is consideration of the problem as such, and legal science finds itself in precisely this situation (Viehweg 1974, 97). Thus the parts, concepts and sentences of jurisprudence must be linked to the problem, and its structure can be understood only from the direction of the problem (Viehweg 1974, 97). This corresponds exactly with his definition of topical reasoning, and so Viehweg concludes that legal reasoning, as problem-based thinking, is topical reasoning. There are topoi unique to particular subjects, and Viehweg finds many legal topoi in the digesta (Viehweg 1974, 56). According to him, there are two kinds of topics (Viehweg 1974, 35): first-level topics and second-level topics; the first is topical reasoning based on an implicit leading point of view, the second uses catalogues of such leading points of view. Lawyers, he says, work with second-level topics and therefore with topoi catalog (Viehweg 1974, 56). Viehweg's research was continued by others such as Gerhard Struck, who provided such a catalogue in 1971. This consists of 64 legal topoi, including such diverse items as Lex posterior derogat legi priori [A special law repeals a more general one (on the same subject).] (topos 1), Nemo plus iuris transferre potest quam ipse habet [No one can transfer to another one more rights than he himself possesses.] (topos 16), "purpose" (topos 57), "interest" (topos 58), etc. (Struck 1971, 20-34). Although Struck's catalogue was often criticised, it should be recognised as an important step towards a better understanding of topical reasoning, not only within legal argumentation but for argumentation in general.

\section{A concept of "topos"}

After this brief introduction we have to discuss the concept of "topos", concentrating only on the constructive and the material sense of the concept, since the mnemonic sense is outside our field of interest. As an axiom we presume that topical reasoning really exists and that it does not oppose rationality, although it antagonises the Cartesian type of rationalist reasoning. The really controversial question is only that of the best method of achieving rationality. In addition, we assume that topical reasoning is much more frequent than Cartesian reasoning, because it is applied in many occasions when practical rationality is required, e.g., in medicine, engineering, politics, military strategy and-last but not least - in legal argumentation. The inspiration for our set of essential characteristics of topoi comes mostly directly from Aristotle.

The first characteristic is that topoi are propositions or concepts providing premises of arguments used in dialectical discourse. In the Aristotelian sense, topoi can be seen as items on a check-list, i.e., points or questions reflecting possible problems. Screening through such a list is obviously a method for arriving at premises. Nevertheless, the initial ("geographical") metaphor of "topos" as a place where one can find 
something useful for building premises indicates that there are actually two possibilities: First, topoi could be places where we directly find premises. Here topoi are propositions, linguistically typically represented on the sentence and text level. But topoi could also be places where we do not directly find premises but only ideas about how to build them. In this case topoi are concepts, linguistically typically represented by linguistic units below the sentence level, e.g., words (see Perelman \& Olbrechts-Tyteca 2000, 83). Thus topoi can be either propositions or concepts. In the realm of law, Struck's topos No. 29 (iura scripta vigilantibus sunt) [The laws are written for those who pay attention.] (Struck 1971, 27) is an example of the first kind and his topos No. 13 ("fair compensation") is an example of the second (see also Struck 1971, 14).

The second characteristic says that topoi must possess a certain degree of generality. Again, we consider the ("geographical") metaphor of "topos" as a place for finding premises, which implies that a topos is bigger than the things it contains. In linguistic terms, this means that a topos is a proposition or concept that is more general than the premises it helps to build. Thus the statement "Paris is the capital of France", for instance, is not a topos, but the statement "Paris is the capital of love" is.

Aristotle's third essential idea, that topoi enjoy a certain degree of general collective acceptance as being plausible, has already been mentioned. Since this is a central point of his theory, it is discussed in the first paragraphs of the Topica. Here he gives a definition of "general [collective] acceptance", which reads: "On the other hand, those opinions are 'generally accepted' which are accepted by every one or by the majority or by the philosophers - i.e., by all, or by the majority, or by the most notable and illustrious of them." (Aristotle 1963, 100a). It is a trivial fact that this does not include the guaranty that any argument build upon such an accepted topos is automatically accepted as well (see Weinberger 1973, 22).

We shall now discuss a few non-essential but frequent characteristics of topoi, for which we use the first three classical canons of rhetoric as a framework. These canons belong to the well-known list of five classical canons of rhetoric: inventio, dispositio, elocutio, memoria and actio, and not only characterize idealised stages of speech production but are also dimensions of any rhetorical product. Therefore they are suitable for rhetorical analysis.

The aspect of inventio: This concerns the question, which content a topos concerns. Aristotle was probably the first who separated "common places", i.e., topoi that could be used for any problem, from "special topoi" that depend on a special science or profession (Aristotle 1959, 1384a; see Perelman \& Olbrechts-Tyteca 2000, 83). Here, we shall distinguish between the following three categories: (1) Abstract topoi, (2) professional topoi and (3) topoi of human life:

(1) Abstract topoi may follow from Aristotle's four predicables (proprium, genus, definition and accident [Aristotle 1963, 101b]), but 
also from his ten categories of predicates (essence, quantity, quality, relation, place, time, position, state, activity and passivity [Aristotle $1963,103 \mathrm{~b}])$ or the respective equivalents from other authors such as Cicero's 19 loci (Cicero 1993, 11-13 [II, 9-11],) etc. They can help to build premises for discussing the most general problems of philosophy and mathematics.

(2) Professional topoi-as mentioned above, Viehweg calls them 'topoi unique to particular subjects's - are used for the purpose of a specific profession, e.g., medicine, ethics, legal argumentation etc., An example of a purely legal topos is: Nemo plus iuris transferre potest quam ipse habet.

(3) Topoi of human life are related to questions or problems of human life in general. They may or may not be related to specific typical problems of human life. Examples of topoi with relation to typical problems are: "Where there is no trust there is no love" (= problem of establishing and maintaining social relations); "Ignorance of the law excuses no man" (= problem of social control). Examples of topoi without relation to typical problems are "Birds of a feather flock together."

The aspect of dispositio: This means the inherent structure of topoi. As stated above, topoi can be propositions or concepts, usually represented below or above the sentence level. Struck, for example, mentions Res iudicata pro veritate accipitur [A matter is decided is accepted for the truth.] (Struck 1971, 21) (= sentence) or "appropriateness" (Angemessenheit) (Struck 1971, 30) (= word).

Another important structural question is the relation between topoi and argument schemes. Perelman and Olbrechts-Tyteca write: "As used by the classical writers, loci [= topoi] are headings under which arguments can be classified."5 (Perelman \& Olbrechts-Tyteca 2000, 83). Kienpointner, who presented one of the most interesting systems of argument schemes (Kienpointner 1992), understands topoi as contentrelated rules of inference, which he takes as "warrants" in the sense of Steven Toulmin's model of argument (Kienpointner 1992, 179; see Toulmin 1958). Since topoi lead to premises, and premises lead to arguments, topoi and argument schemes correspond with each other. Thus, wherever there is an argument scheme there is also a topos. Kienpointner's mentioned system consists of the following categories and subcategories (Kienpointner 1992, 246):

I. Argumentation schemes using rules of inference: (1) schemes of categorization: (a) definition, (b) genus-species, (c) the whole and a part); (2) schemes of comparison: (a) equality, (b) similarity, (c) difference (d) a maiore/a minore); (3) schemes of opposition: (a) contradictory opposition, (b) contrary

\footnotetext{
${ }^{5}$ Original with italics.
} 
opposition, (c) relativity

(d) incompatibility; (4) schemes of causality: (a) cause, (b) effect, (c) reason, (d) result, (e) means, (f) purpose.

II. Argumentation schemes establishing rules of inference: (1) inductive example.

III. Argumentation schemes neither using rules of inference like in (I) nor establishing them like in (II): (1) illustrative example; (2) analogy; (3) authority.

Thus, if topoi correspond with argument schemes and argument schemes are exhaustively comprised by Kienpointner's system, this system can be applied to topoi as well.

The aspect of elocutio: This tackles the question of how topoi are verbalised. We have just said that topoi can be linguistically represented below or above the sentence level. In the latter case, they can have the structure of implicit or explicit conditionals (see, e.g., Edgington 2001), such as Si duo faciunt idem non est idem [If two persons do the same it is still not the same.] Topoi are rarely formulated in plain style (genus tenue/humile) but usually by using a rhetorically elaborate style, often in an almost artistic manner (genus medium or genus grande/sublime) by using rhetorical figures and tropes - especially metaphors. Very often the linguistic design is a saying, proverb, aphorism, etc.

To sum up: Topoi are general propositions or concepts that provide premises of arguments used in a certain discourse and are collectively accepted by the participants in the discourse as being plausible. They can tackle problems of abstract philosophy, of a specific profession or of human life in general. They usually have fixed structure and are linguistically expressed by one (or a few) word(s) or sentence(s), have a fixed structural and linguistic design, and are generally formulated in a rhetorically elaborate style.

\section{Topics in contemporary legal argumentation}

Finally we will briefly discuss the role of topics for legal argumentation - a question mainly provoked by Viehweg's claims (see also Calboli 2000; Horn 1967; Merin 2005; Weinberger 1973). Our analysis is restricted to the Continental European legal tradition and shall bring us to the central point of the article, which states that legal argumentation is essentially topical - though not in the sense understood by Viehweg.

First, we shall have a very brief look at the nature of (Continental European) legal argumentation. We start by imagining two children, A and B. A is arguing with her parents about bedtime (yes, that happens); B is in school doing mental calculation. Both children are reasoning, but quite differently. The first important difference lies in the fact that $\mathrm{A}$ needs no special training, but reasons intuitively. B, on the other hand, 
basically applies what she has previously studied, thus employing a culturally developed mental technology. The second and even more important difference is that B reasons by applying strictly defined rules. Only if she does it this way will the results be mathematically correct (and the teacher satisfied). Mental calculation is the prototype of formal reasoning, which includes logic and mathematics. This is similar to Vico's and Viehweg's Cartesian rationalist reasoning ("more geometrico reasoning") and very different from legal reasoning. Following the usual terminology, we provide the following definitions: any reasoning requiring that all inferences need to be processed according to strictly defined rules shall be called 'formal reasoning' and all other reasoning 'informal reasoning'. It is obvious that according to these definitions legal argumentation is more or less completely informal.

It is important to note that also informal reasoning is not arbitrary, but subject to regulation. This is carried out by pragmatic discourse rules (that are actually social rules), and it should be emphasised that legal discourse displays an extraordinary number of such regulations. We might say that the rationality of legal discourse is chiefly established by these rules. Let us name only one important occurrence of these rules, the idea of lege artis argumentation: In an informal discourse as in the legal one it is much more difficult to define what is rational and what is irrational than it is in mathematics, for example, because invalid derivations are much easier to prove. The solution of the legal community for this problem is the implementation of pragmatic discourse rules, established by collective acceptance. So lawyers establish rules for deciding what is or is not appropriate argumentation. This leads to a metadiscourse based on a concept of lege artis argumentation, signifying that lawyers communicate not only about legal problems but also about the question of which arguments are allowed and which are not. This basically regulates the way in which agents of legal discourse have to argue in order to reach certain goals, especially collective acceptance.

Given these conditions, there is the question, what exactly can become a possible topos of legal argumentation or reasoning. It is important to note, that here we are interested in the general scheme but not in the right application of topoi for concrete problems that obviously depends on situations and contexts.

Two answers are possible and the first says that these are exactly the topoi from Struck's catalogue (see Struck 1971, 20-34). As we have said, Viehweg stated explicitly that legal argumentation works with topoi catalogues and Struck's catalogue is the natural continuation of this approach. So, it is only natural to start with it. Struck regards topoi mainly as standard arguments and his catalogue is intended to reflect their distributions within legal discourse (Struck 1971, 20). Most of Struck's topoi are professional legal topoi (some are topoi of human life) and all of them fulfil our definition of "topos" (see above). Although the topoi on this list are the most well known general principles of law, they are merely Struck's selection, and according to our definition of the 
concept of topos there are more topoi in the realm of law than there are on his list. We shall name Struck's topoi 'topoi in the strong sense'. For scrutinising Viehweg's claims, we shall take Struck's catalogue and look for typical linguistic expressions of these topoi in legal texts, such as court decisions. The strength of Viehweg's claims facilitates the test, since a glance should be enough to find features of outstanding importance. Screening legal databases should therefore suffice. The author searched the Austrian RIS-database (http://www.ris.bka.gv.at/), which documents 85805 Austrian Supreme Court decisions up to 5 February 2007. 304 of these refer to the topos "lex specialis derogat legi generali", 29 to the topos "lex posterior derogat legi priori" and one to the topos "nemo plus iuris transferre potest quam ipse habet". Of course, not all topoi are formulated in Latin, but since these three legal topoi are among the most popular, we may assume that these results are no exception, but representative of legal argumentation as a whole. Thus if we take topoi in the strong sense, the quantitative information available disproves Viehweg. Nevertheless, it should be noted that the number of references to topics in the strong sense is not zero. So topical reasoning even in this sense does actually play a role - though only a minor one.

Since the first possible answer is unsatisfying, we have to think of another one. Therefore we will introduce the concept of "topos in the weak sense", stating that anything within the realm of law that fulfils our above-mentioned definition of "topos" is a topos in this sense. Legal discourse knows no a priori restriction of possible arguments, thus all topoi behind Kienpointner's mentioned argument schemes can possibly be topoi of legal argumentation. This is our second answer.

Of course within legal discourse there is a posteriori selection, i.e., a selection which possible topoi can and must be applied lege artis [according to the law of the art] in which situations, for which problems, etc. This selection is carried out by the already mentioned discourse rules but cannot be discussed in detail within the course of this paper. Nevertheless, it is worth mentioning, that this is the decisive element within legal argumentation and reasoning, and that sciences knows amazingly little about its underlying mechanisms.

\section{Conclusion}

Viehweg rightly emphasised the importance of topics in legal argumentation and reasoning. However, he aimed at the wrong class of topoi, i.e., topoi in the strong sense. These topoi do indeed exist but they do not play a major role. Topoi in the weak sense are much more important. These topoi correspond with the argument schemes in Kienpointner's system, and saying that topoi in the weak sense are important for legal discourse is the same as saying that legal argumentation is important. This, however, is not as trivial as it may sound, because many legal scholars would actually object (see Bertea 
2004, 465). Nevertheless, what really shapes legal discourse are the pragmatic discourse rules, of which we have mentioned the idea of lege artis argumentation (other important examples are the ideas of class consciousness, reputation and rationality by procedure [for a more detailed discussion see Kreuzbauer 2007]). The underlying mechanisms of these discourse rules are still not sufficiently understood. So, this is the direction further research should go to.

\section{References}

Aarnio, A. (1987). The Rational as Reasonable: A Treatise in Legal Justification. Dordrecht et al.: Reidel.

Aarnio, A., Alexy, R., \& Peczenik, A. (1981a). The Foundation of Legal Reasoning (I). Rechtstheorie, 12, 133-158.

Aarnio, A., Alexy, R., \& Peczenik, A. (1981b). The Foundation of Legal Reasoning (II). Rechtstheorie, 12, 257-279.

Aarnio, A., Alexy, R., \& Peczenik, A. (1981c). The Foundation of Legal Reasoning (III). Rechtstheorie, 12, 423-448.

Alexy, R. (1991). Theorie der juristischen Argumentation: Die Theorie des rationalen Diskurses als Theorie der juristischen Begründung $\left(2^{\mathrm{nd}}\right.$ ed.). Frankfurt am Main: Suhrkamp.

Aristotle. (1959). Rhetorica (W. R. Roberts, Trans.). In W.D. Ross (ed.), The Works of Aristotle Translated into English (Vol. 11 [Rhetorica, De Rhetorica ad Alexandrum, De Poetica], pp. 1354a-1420b). London: Oxford University Press.

Aristotle. (1963). Topica (W.A. Pickard-Cambrigde, Trans.). In W.D. Ross (Ed.), The Complete Works of Aristotle Translated into English, (Vol. 1 [Categoriae and De Interpretatione, Analytica priora, Analytica posteriora, Topica and Sophisticis elenchis], pp. 100-164). London: Oxford University Press,.

Bertea, S. (2004). Certainty, Reasonableness and Argumentation in Law, Argumentation 18, 465-478.

Calboli, G. (2000). Die Topik in Jurisprudenz und Rhetorik. In T. Schirren \& G. Ueding (eds.), Topik und Rhetorik: Ein interdisziplinäres Symposion (Vol. 13, pp. 555-565). Tübingen: Max Niemeyer.

Cicero, M.T. (1993). Topica: Die Kunst, richtig zu argumentieren (lateinisch und deutsch) (K. Bayer, Trans.). Darmstadt: Wissenschaftliche Buchgesellschaft.

Conley, T. (2000). What Counts as a Topos in Contemporary Research? In T. Schirren \& G. Ueding (eds.), Topik und Rhetorik: Ein interdisziplinäres Symposion (Vol. 13, pp. 579-585). Tübingen: Max Niemeyer.

Copi, I.M., \& Cohen, C. (2002). Introduction to Logic $\left(11^{\text {th }}\right.$ ed.). Upper Saddle River (NJ): Prentice Hall. 
Die juristische Argumentation. Vorträge des Weltkongresses für Rechtsund Sozialphilosophie, Brüssel 29.08.-03.09.1971 [no editor] (1972). Wiesbaden: Franz Steiner Verlag.

Edgington, D. (2001). Conditionals. In L. Goble (ed.), The Blackwell Guide to Philosophical Logic (pp. 385-414). Oxford et al.: Blackwell.

Eemeren, F. H. v., \& Grootendorst, R. (2004). A Systematic Theory of Argumentation: The Pragma-dialectical Approach. Cambridge et al.: Cambridge University Press.

Feteris, E.T. (1999). Fundamentals of Legal Argumentation: A Survey on the Justification of Judicial Decisions. Dordrecht et al.: Kluwer Academic Publishers.

Fuhrmann, M. (2000). Die zivilrechtlichen Beispiele in Ciceros Topik. In T. Schirren \& G. Ueding (eds.), Topik und Rhetorik: Ein interdisziplinäres Symposion (pp. 51-66). Tübingen: Max Niemeyer.

Gethmann, C.F. (1996). Topik. In J. Mittelstraß (ed.), Enzyklopädie Philosophie und Wissenschaftstheorie (Vol. 4, pp. 319-321). Stuttgart et al.: J.B. Metzler Verlag.

Goldmann, S. (1998). Topik; Topos (III.). In J. Ritter \& K. Gründer (eds.), Historisches Wörterbuch der Philosophie (Vol. 10, columns 1279-1288). Basel et al.: Schwabe.

Horn, N. (1967). Zur Bedeutung der Topiklehre Theodor Viehwegs für eine einheitliche Theorie des juristischen Denkens. Neue Juristische Wochenschrift, 20, 601-608.

Holyoak, K.J. \& Morrison, R.G. (2005). Thinking and Reasoning: A Reader's Guide, in: K. J. Holyoak \& R. G. Morrison (eds.), Cambridge Handbook of Thinking \& Reasoning. Cambridge University Press, New York et al., 1-9.

Kalivoda, G. (2007). Typologie der Topik. In G. Kreuzbauer, N. Gratzl \& E. Hiebl (eds.), Persuasion und Wissenschaft: Aktuelle Fragestellungen von Rhetorik und Argumentationstheorie (pp. 129142). Wien: LIT-Verlag.

Kienpointner, M. (1992). Alltagslogik: Struktur und Funktion von Argumentationsmustern. Stuttgart et al.: Frommann-Holzboog.

Kienpointner, M. (2000). Topoi/loci - sprachliche oder außersprachliche Größen? In T. Schirren \& G. Ueding (eds.), Topik und Rhetorik: Ein interdisziplinäres Symposion (Vol. 13, pp. 609-622). Tübingen: Max Niemeyer.

Kopperschmidt, J. (2000). Argumentationstheorie zur Einführung. Junius, Hamburg.

Kreuzbauer, G. (2004). Kleine Einführung in die Forschungsgeschichte der juristischen Argumentationstheorie. In G. Kreuzbauer \& S. Augeneder (eds.), Der juristische Streit: Recht zwischen Rhetorik, Argumentation und Dogmatik (pp. 9-25). Wiesbaden et al.: Franz Steiner. 
Kreuzbauer, G. (2007). Ist Recht die bessere Ethik? In M. Fischer \& M. Strasser (eds.), Rechtsethik (Vol. 6, pp. 65-86). Frankfurt am Main et al.: Lang.

MacCormick, N. (1978). Legal Reasoning and Legal Theory. Oxford et al.: Clarendon Press.

Merin, A. (2005). Topik und Wahrscheinlichkeit im juristischen Argument. In B. Schünemann, M.-T. Tinnefeld \& R. Wittmann (eds.), Gerechtigkeitswissenschaft - Kolloqium aus Anlass des 70. Geburtstages von Lothar Philipps (pp. 103-115). Berlin: Berliner Wissenschafts-Verlag.

Neumann, U. (1986). Juristische Argumentationslehre. Darmstadt: Wissenschaftliche Buchgesellschaft Darmstadt.

Peczenik, A. (1982). Rationality of Legal Justification. Archiv für Rechtsund Sozialphilosophie, 68, 137-163.

Peczenik, A. (1983). Grundlagen der juristischen Argumentation. Wien et al.: Springer.

Perelman, C., \& Olbrechts-Tyteca, L. (2000). The New Rhetoric: A Treatise on Argumentation (J. Wilkinson \& P. Weaver, Trans.). Notre Dame (IN): University of Notre Dame Press.

Prakken, H. (1997). Logical Tools for Modelling Legal Argument: A Study of Defeasible Reasoning in Law. Dordrecht et al.: Kluwer Academic Publishers.

Primavesi, O. (1998). Topik; Topos (I.: Antike). In J. Ritter \& K. Gründer (eds.), Historisches Wörterbuch der Philosophie (Vol. 10, columns 1263-1269). Basel et al.: Schwabe.

Rapp, C. (2002). Aristotle's Rhetoric. Retrieved 2007.01.17, from http://plato-stanford.edu/entries/Aristotle-rhetoric.

Sartor, G. (2005). Legal Reasoning: A Cognitive Approach to the Law. Dordrecht et al.: Springer.

Schirren, T. (2000). Einleitung. In T. Schirren \& G. Ueding (eds.), Topik und Rhetorik: Ein interdisziplinäres Symposion (pp. XIII-XXXI). Tübingen: Max Niemeyer.

Skyrms, B. (1989). Einführung in die induktive Logik (G.J.W. Dorn, Trans.). Frankfurt am Main et al.: Peter Lang Verlag.

Sprute, J. (2000). Topik bei Isokrates. In T. Schirren \& G. Ueding (eds.), Topik und Rhetorik: Ein interdisziplinäres Symposion (pp. 3-13). Tübingen: Max Niemeyer.

Struck, G. (1971). Topische Jurisprudenz: Argument und Gemeinplatz in der juristischen Arbeit. Frankfurt am Main: Athenäum Verlag.

Toulmin, S.E. (1958). The Uses of Argument. Cambridge: Cambridge University Press.

Vico, G. (1963). De nostri temporis studium ratione/Vom Wesen und Weg der geistigen Bildung (W. F. Otto, Trans. 2 ed.). Darmstadt: Wissenschaftliche Buchgesellschaft.

Viehweg, T. (1953). Topik und Jurisprudenz: Ein Beitrag zur rechtswissenschaftichen Grundlagenforschung. München: Beck. 
Topics in Contemporary Legal Argumentation 85

Viehweg, T. (1974). Topik und Jurisprudenz: Ein Beitrag zur rechtswissenschaftlichen Grundlagenforschung (5 $5^{\text {th }}$ ed.). München: Beck.

Viehweg, T. (1993). Topics and Law: A Contribution to Basic Research in Law (W.C.J. Durham, Trans.). Frankfurt am Main et al.: Lang.

Weinberger, O. (1973). Topik und Plausibilitätsargumentation. Archiv für Rechts- und Sozialphilosophie, 59, 19-36.

Wolters, G. (1984). more geometrico, in: J. Mittelstraß (Ed.), Enzyklopädie Philosophie und Wissenschaftstheorie. Bd. 2. B.I.Wissenschaftsverlag, Mannheim et al., 939. 